\title{
Evaluating the Gas Flaring Commercialisation Policy in Nigeria: An Agenda for Mitigating Gas Flaring
}

\author{
Dr. Samuel C Dike ${ }^{1 *}$ and Soboma Odimabo -nsijilem \\ 1 LLM, Ph.D (Aberdeen) UK ACairb ,( Scotland ) AMEI (London) Notary Public ( Nigeria) Associate \\ Professor of Energy Law and Head of Department, Jurisprudence and International Law, Rivers State University, \\ Port Harcourt, Nigeria \\ 2 Lecturer LLM Dundee, Department of Business law; Lecturer Faculty of Law, Rivers State
}

\begin{abstract}
Nigeria is an oil and gas producing country but sadly its gas sector had suffered serious setback in terms of development and utilisation. Although, the crude oil sector is nearing maturity, the gas sector is still in its infancy due to some past regulatory mistakes. As a result of low gas utilization and past development policies, gas flaring became the bane of the petroleum industry in Nigeria for over five decades and this is with no end in sight. Amidst, the abundant natural gas reserves, the country was considered one of the worst gas flaring nations after Russia. Past policies and legal regimes to reduce gas flaring were rather episodic and unrealistic due to several reasons notably: policy instability, lack of cooperation by the International Oil Corporations (IOCs) and the lack of political will by the Federal Government. Gas flaring in Nigeria contributes to both economic waste as well as a huge environmental challenge in the oil and gas producing communities. It was against this background that the Federal Government recently announced measures for the utilisation of flared gas from the Niger Delta region. The objective is to make hitherto gas flared to be commercially utilised thereby reducing their environmental footprint. The significance of this paper is to examine the efficacy of these inchoate government policies and their fit for purpose. The paper found that any such measure must be backed up with enforcement mechanism with attractive terms for new entrants into the gas sector development in Nigeria.
\end{abstract}

Keywords: Gas Sector, Gas Development, Utilisation, Flaring, and Nigeria.

DOI: $10.7176 / \mathrm{JLPG} / 96-15$

Publication date: April $30^{\text {th }} 2020$

\section{Introduction.}

Recently, the Federal Government of Nigeria established Gas flaring Commercialisation Policy to promote gas utilisation, domestic consumption and exports of gas. (Nigeran gas commercialisation policy 2019). This policy was based on the poor gas utilization regime and the adverse environmental footprint of flared gas in Nigeria. the past gas legal frameworks and policy were characterised by unenforceable provisions and low penal regime which made them to be easily ignored or flouted by the International Oil Companies (IOCs ) and other investors in the gas sector in Nigeria( Environmental Right Action. Action 2005). This wanton flaring and venting of gas represent the past developments in the gas sector and has continued up till date. This act of faring and unwarranted venting of gas has brought untold economic losses to Nigeria, aggravated adverse environmental degradation in oil and gas producing communities, contributed to poor human, safety and health conditions and is a precursor to climate variability Federal Government of Nigeria 2003 and 215). Consequently, Nigeria was regarded as one of the worst gas flaring nations until it established the Nigerian Liquefied Natural Gas Company in Bonny, Rivers State around 1990 and other gas gathering projects as can be seen later in this work. This, development with the gas fare master plan initiated by the Federal government; considerably mitigated the gas flared footprint and the country's unenviable record. (Ebuchu, 2008). Further, the consumption of gas by the middle class in Nigeria equally increased due to the negative impact of flared gas on climate, environment and health of Nigerians. The Federal Government's Policy and other legal frameworks in Nigeria have never been pro- poor but institutionalised to favour the Government's export revenue from oil and gas. ${ }^{1}$ Energy Commission of Nigeria's National Energy Policy 2003, although, has as one of its objectives- to make oil and gas products available to Nigerians in a sustainable way, has remained largely a policy without legislative backing. Rather than establishing a domestic supply obligation, which will in turn galvanise domestic utilization and consumption of gas at affordable prices in order to alleviate the sufferings of the Nigerian people, the government has tailored its natural gas policy, like the oil sector, towards economic and political gains only without considering the environmental impacts.. In addition, the past legal regime in Nigeria both at the sectoral and general levels did not significantly promote the development of the oil and gas producing areas. Petroleum Drilling Production Regulation 1969 made pursuant to section 9 of the Petroleum, Act 1969, Reg 43 which provide for the licensees to inform government of any measures for the utilisation of natural gas and for this reasons the IOCs are quite unhappy with the request by FGN for them to account for natural gas produced from previously licensed fields and hence preferred to flare gas in there are of operations being the Niger delta region. Consequently, as result, there has been serious acts of sabotage of petroleum infrastructure by indigenes of these communities and states (Akpan, 2005). These acts include: the cutting of oil and gas pipelines, setting up of illegal refining companies, kidnapping and hostage taking of oil workers, stealing of oil and gas equipment's, piracy and other terrorist activities on petroleum transportation high ways among others (Omorogbe, 1996). 
The past emphasis on government had been based on the maximisation of the crude oil contribution to the Nigerian government's export revenue take to the detriment of the gas sector development and community participation ( Dike ,2015). This was because Crude oil was considered more economical than natural gas both in the eyes of government and its investors -the IOCs. Thus, as a result, gas flaring gained prominence among the major oil and gas investors in Nigeria than in any oil and gas producing country in Africa. The flared gas could be reinjected, utilised for sundry purposes and benefits. It could contribute to electricity generation for fertilizer production, for the use of sundry industrial activities and for better improved domestic uses. A proper gas utilisation, management and regulation agenda will promote sustainable development and help in meeting the global sustainable development agenda of the United Nations. This is because natural gas is considered environmentally cleaner than crude oil. This research focusses on the examination of the recent federal government policy on gas utilisation and commercialisation. The objective is to see is efficacy, barring any clog on the wheel of promoting efficient gas utilization and commercialisation policy which is environmentally friendly and in line with global best practices. This paper will examine the natural gas potentials of Nigeria, the past gas gathering projects and legal frameworks. The paper shall then evaluate the recent federal government commercialisation policy and conclude by making informed recommendations.

\section{Nigeria's Natural Gas Potentials}

Nigeria is one of the top nations in the world with huge gas reserves and ranked the $9^{\text {th }}$ largest in the world.( Chevron 2019) Its's estimated proven natural gas reserves was measured 157 Trillion cubic feet as at 1996 (Aghalilo2009) $^{1}$ In 2012, the country was estimated with 187 trillion standard cubic feet of gas (TSCF) with production estimated at 8: 24 billion standard cubic feet of gas per day (SCFD), which is made up 98 (TSCF) of associated gas (AG) and 89 TSCF of non-associated gas with a combined total of the proved, probate and possible reserves estimated at 300 TSCF. ( Nawozuzu2014) Currently, Nigeria has around 202 trillion cubic feet (TCF) of proven gas reserves plus about $600 \mathrm{TCF}$ unproven gas reserves (This day Newspaper 2102). ${ }^{2}$ The current gas supply is enough to support about 5 giga watts $(\mathrm{GW})$ of power generating capacity and also about three(3) times the value of her crude oil reserves. Nigeria's current gas production is in the region of 8.5 billion standard cubic feet per day (BSCFD), with volume of about $3.7 \mathrm{bscfd}$, representing 43 percent of total gas production been exported, while 2.7 bscfd-32 percent of total gas production is used in the upstream for gas re-injection and gas lift. 1.5 bscfd-18 percent of the total gas production is used domestically for power generation and industries, leaving the balance of $0.6 \mathrm{bscfd}$ representing seven percent of total gas production, currently being flared at fields in the Niger Delta region of the country. The most dominant natural resources in Nigeria is natural gas, having a reserve to be twice that of its oil reserves (DPR 2013). However, research over the years has shown that the exploration of gas in Nigeria is limited and much of the gas flared. Thus eestimates from the World Bank suggest that huge amounts in excess of 100billion cubic meters of natural gas are burnt yearly.(Oyewo, 2011) This figure is stated to add up to approximately 30.6 billion dollars which is double the total consumption for Africa, thus making Nigeria the sixth-largest gas-flaring country globally (World bank 2018),( Schichi ,Myles, Okelum 2018)

\section{1 .Nigeria's Natural Gas Policy}

The Nigerian National Gas policy are initiatives by the government with an objective to maximise the oil and gas sector's value to the economy and transit from an oil industry to an integrated oil and gas industry ( Onyekwu, 2009). These initiatives have been geared towards boosting the domestic market and realize maximum revenue possible from gas. As a result, the gas policy framework in Nigeria has been undergoing series of reforms and new policy initiatives starting with the Natural Gas Strategy in 2003, the Natural Gas Policy (2004), Draft Natural Gas (Fiscal Reform) Act (2005) (also known as Draft Downstream Gas Act) and finally, the precursor to the Policy, the Gas Master Plan (GMP) (2008) (National Gas Policy 2017). The Gas Masterplan in the bid of utilizing the natural gas sector in the country, introduced the Domestic Gas Supply Obligation, the Gas Pricing Framework and the Gas Infrastructure blueprint.

Thus; the Domestic Gas Supply addresses the issue of domestic gas supply availability in the country. The Price Policy adopted a gas pricing framework to cover areas of the domestic sector (residential users), Industrial sector (for industrial uses like utilising gas for feedstock in the creation of new products like fertilizers, methanol and GTL) and for the Commercial sector (for manufacturing industries that uses gas for industrial fuel). The Nigerian Gas Infrastructure Blueprint designed an integrated infrastructure strategy to support domestic, regional and export LNG markets. It ensured connectivity between major gas reserves sources and the demand centres through the Central Processing Facilities (CPFs). The CPFs serve as major gas hubs where wet gas from the gas fields are treated and processed to provide a flexible supply grid nationwide and facilitate more flexibility in gas supply 
deliverability across the country. Thus, it provides for three (3) domestic systems in Nigeria;

I. The Western System comprising the existing Escravos Lagos Pipeline System (ELPS) and a new offshore extension to Lagos.

II. The first South-North gas transmission line. This will take dry gas from the Akwa Ibom/Calabar facility to Ajaokuta, Abuja, Kano, Katsina. The line will serve the Eastern states of Anambra, Abia, Ebonyi, Ebonyi, Enugu and Imo

III. An inter-connector that links the Eastern gas reserve canters with the two transmission systems above.

It could be argued that the Federal Government's regulation of domestic gas supply, natural gas pricing and also infrastructure blueprint, appear to be easy to accept theoretically but difficult to sustain in practice. This is drawn from past failed efforts to regulate gas flaring (Associated Gas 1979,1985). Iimplementing a regulated pricing regime in the domestic market is exacerbated by the widely divergent interests of major players in the industry (Gas Pricing 2009). The key dilemma in Nigeria is that while lower gas prices are needed to encourage gas demand and support local industries and power generation, cost-reflective prices are needed to stimulate investment in gas infrastructure and assure supply sustainability. Findings show that the scale of the problem is further compounded by the fact that the various domestic demand sectors have varying capacity to accommodate cost-reflective gas prices. On the other hand, competitive tariffs in international markets can create a preferential pull for exports at the expense of the domestic market if regulated pricing results in lower returns on investments or inability of the gas supplier to cover its costs (NNPC 2008). Also the issue of Infrastructure Blueprint is faced with the challenge of violence occurring in the areas where the oil and gas industries are located. (Omorogbe, 1996). The Niger Delta areas of the country which is the hub of the produced gas are faced with continuous violence, vandalization of pipelines and damage to oil and gas infrastructure.

In 2017, a new National Gas Policy (NGP) was introduced to replace the 2008 Nigeria Gas Masterplan. This new NGP seeks to create a governance framework where the gas sector will be treated as a separate and distinct sector from that of the oil sector. It intends to provide a clear market structure by promoting investments in both the upstream and downstream gas production through the use of Liquefied Petroleum gas (LPG), National Gas Liquid (NGL), and Compressed National Gas Liquid (CNGL) for both industrial and domestic use. In achieving this, the New NGP contains a comprehensive overview of the government's policy and steps to be taken to achieve this objectives. Thus, it aims inter alia:

a. Reform of legislations and regulations in the Gas sector in the country,

b. Enforcement of domestic supply obligations,

c. Reworking the sector to focus on public-private partnership,

d. Providing incentives and opportunities for investment in National Gas products,

e. Developing infrastructure and building Gas markets,

f. Investment in new technology for the capture and utilization of associated gas for power generation,

g. Completely preventing gas flaring and limiting the reinjection of associated gas in oil projects,

h. Replacing diesel with gas as a source of fuel etc.

With the reform of national gas legislations and regulations; the gas pricing regulations, gas network code etc, the NGP will give more comfort to investors in Nigeria gas sector as there will be open access to gas development in the country.

\subsubsection{Nigeria's Natural Gas Laws}

The principal legislations governing the exploration and regulation of Natural gas in Nigeria, is the Constitution of Nigeria (CFRN 1999) and also the Petroleum Act 1969 of the Laws of the Federation of Nigeria 2004.

\section{A) Constitution of the Federal Republic of Nigeria (CFRN 1999)}

Section 44(3) of the Constitution of the Federal Republic of Nigeria provides for an explicit ownership of natural gas in the country being vested on the federal government of Nigeria. Thus, it provides;

"Notwithstanding the foregoing provisions of this section, the entire property in and control of all minerals, mineral oils and natural gas in under or upon any land in Nigeria or in, under or upon the territorial waters and the Exclusive Economic Zone of Nigeria shall vest in the Government of the Federation and shall be managed in such manner as may be prescribed by the National Assembly."

B) The Petroleum Act 1969, CAP 350, Laws of the Federation 2004 regulates the production, exploration and regulation of the gas sector in Nigeria. It also provides the fact that ownership of natural resources including natural gas in the country is vested on the government of Nigeria.

Thus, it provides that; "the entire ownership and control of all petroleum in, under or upon any lands to 
which this section applies shall be vested in the state. Which includes lands covered by water, territorial waters or forms part of the continental shelf in the country' (Petroleum Act 1990).

Under Nigeria's extant petroleum laws, paragraph 35 (b) (i) of the first schedule to the Petroleum Act CAP 350 Laws of the Federation of Nigeria allows for the Federal Government to take natural gas produced with crude oil by a licensee or lessee, free of cost at the flare or at an agreed cost and without payment of royalty. This section has generated conflict between the federal government and the investors and this contributed stalling the growth of the natural gas sector in Nigeria as investors argued that having been granted license over some natural gas rights by the federal government, the rights to call natural gas produced by the federal Government no longer existed(. Petroleum (Drilling and Production) Regulation1991)

It is essential at this point to emphasise that where there is any conflict between the constitution and any law in Nigeria, the provision of the constitution prevails. In Thus, the provision of the constitution prevails regarding the ownership of gas residing with the Minister on behalf of the Federal Government.

The Petroleum Act further gives the Minister powers to;

a. Grant the necessary licences required for oil exploration, oil prospecting and oil mining activities

b. Grant licences for Petroleum, refining, importation, storage and sales services.

c. Exercise the right of pre-emption of all petroleum products in the event of any state or National emergency.

d. Shall exercise general supervision over all operations carried on over licences and lease granted under the Act (Petroleum Act 2004).

However, there are other legislations regulating Natural Gas exploration in Nigeria; which also contributed unwittingly to the slow development of the gas sector in Nigeria. Regulation 43 of the Petroleum (Drilling and Production) Regulation provides that five after the grant of a licence to the licensee, the licensee will furnish the federal government plans and strategies for the utilisation of natural gas produced whether associated with oil or not. It is argued that the period of five years is unreasonably long to brings issues of gas utilisation, gas flare plans to the federal government's attention (Dike, 2015). However, the combined effect of the laws cited above is that they were very unhelpful in promoting agas reduction and strategic investment on Gas

C) Oil Pipeline Act 1990 Laws of the Federation 2004

This Act makes provision of licences to be granted for the establishment and maintenance of pipelines incidental and supplementary to oilfields and oil mining and for purposes ancillary to such pipelines (Oil Pipeline Act 2004). Thus it makes provisions for:

a. giving the minister powers to grant and permit survey routes for oil pipelines and license to construct pipelines.

b. Powers to restrict license in respect of certain public facilities

c. Powers to acquire a land where oil is been found and then compensate the owners of the land.

d. And also powers to terminate pipeline license where the need arises.

This Act made scanty provision concerning gas flaring and reduction

D) Associated Gas Re Injection Act 1979

This Act compels every company producing Oil and Gas in Nigeria to submit preliminary program for gas reinjection and detailed plans for implementation of gas -rejection. Thus it provides for;

a. A duty on every company producing oil and gas in Nigeria to submit a scheme for viable utilization of all associated gas produced from fields and also submit projects to re-inject all gas produced in association with oil, but not utilized in an industrial project.

b. Duty on oil companies to cease the flaring of natural gas.

c. And also penalty for flaring of natural gas offences (Associated gas Re Injection Act 1979)

Due to the paucity of the provisions coupled with the low fines, most IOCs preferred to flare gas than to re inject as provided under the extant law

E) Nigeria Oil and Gas Industry Contents Development Act 2010 (NOGCDA)

The Act provides for the development of Nigerian content in the oil and gas industry, Nigerian content plan, supervision, implementation and for other related matters, This Act provides for; 
1. The recognition of Nigerian ingenious oil and gas operators and gives them precedence in awarding of oil blocks, oil lifting licenses and all other contract.

2. The establishment of the Nigerian Content Development and Monitoring Board (NCDMB) to implement the provisions of the Act, make procedural guidelines and monitor compliance by operators within the industry.

3. There is also provision in the Act for a Nigerian Content Development Fund which is established for the purpose of funding the implementation of Nigerian content development in the Nigeria oil and gas industry.

\section{F) Deep Offshore and Inland Basin Production Sharing Contract Act 2004}

This Act provides for certain fiscal incentives to be given to the oil and gas companies operating in the Deep Offshore and Inland Basin areas under production sharing contracts between the Nigerian National Petroleum Corporation or other companies holding oil prospecting licenses or oil mining leases and various petroleum exploration and production companies. The Act provides for :

I. Production sharing contacts.

II. Issuing of licenses.

III. Determination of petroleum profit tax.

IV. Royalty payable in respect of deep offshore production sharing contracts.

Recently, the Deep Offshore and Inland Basin Production Sharing Contract Bill 2019 has been presented to the National Assembly for review of the provision of section 16 of the DOIBPSC Act 2004; to such extent that it will be economically beneficial to the government of Nigeria. This is consequent upon its periodic review provision which is provided under section 16 of the DOIBPSC Act 2004. From the above legislations, it is eminent to state that there are legal constraints in the mitigation and utilization of natural gas in Nigeria. Majority of the laws enacted are directly linked to the Oil sector and there is no separate legislation recognizing downstream gas as a commodity. Attempts to mop up gas and provides for utilization led to the establishment of downstream gas utilization projects. 5

\section{3.. Nigeria's Existing Natural Gas Projects}

For the international market, NNPC and its Joint vventure partners have embarked on several gas utilization projects, which include the following:

\section{1) Escravos Gas Project:}

The Escravos Gas Project was established for the purpose of solving the incessant flares and waste of natural gas in Nigeria. It was a joint project among Chevron Nigeria Limited (CNL) $(75 \%$ share and the Nigerian National Petroleum Company (NNPC) (25\% share) constructed the 33,000 barrel per day (bpd) Escravos Gas-to-Liquids (EGTL) plant in Escravos site, Delta state, Nigeria. This is expected to be expanded to a 120,000bpd capacity within ten years of its completion. (Excravos 1998) ${ }^{1}$ This joint venture processes gas to Liquid plant (EGTL) and converts natural gas into a premium environmentally friendly by-product; fuel, diesel and gas to liquid (gtl) naptail products. This is done by converting more than 325 million cubic feet of natural gas daily and producing the LPG for sale to the international market and domestic market. The EGP-1 project, which cost $\$ 550 \mathrm{~m}$, was completed in 1997. EGP-2 came on-stream in 2003 and phase 3A was completed in 2009. The EGP project is currently in phase 3B of expansion and commenced full operation in 2013. In September 2000 Sasol, a South African Energy and Chemical Company and Chevron signed the final agreements on the GTL projects, using leading technologies and technical expertise of Salso Chevron (Salso's proprietary Fischer-Tropsch Technology and Chevron's Proprietary Isocracking Technology), to provide management, operating and technical services to the project owner (Abgonifo, 2016). Salso and Chevron will also market products from EGTL to primary market in Europe and USA This project entails high cost investment in its operational activities, yet Chevron considers it a longterm viable solution to Nigeria's natural gas flaring crisis. 


\section{2) Oso NGL Project:}

The OSO NGL project located in Bonny Island, Southern Niger Delta is a joint venture between Mobil (ExxonMobil) and the NNPC. Mobil holds 51\% shares, while the NNPC holds 49\% shares. The project commenced production of 30,000 barrels a day in 1998, and production is anticipated to rise at a peak of 50,000 bpd of mixed propane/butane for export. This project otherwise known as the OSO Condensate Field Development Project aims at increasing Nigerian hydrocarbon exports by recovering 350 million bbl of NGL from Oso field which has been producing condensate since 1992(Mobil1995) thereby enhancing significantly, the country's foreign exchange earnings. ${ }^{1}$ The $\$ 1.3$ bn project is designed to gather gas from all the MPN fields, compress, extract NGL and inject lean gas to recover $275 \mathrm{~m}$ barrels of natural gas liquids from associated gas produced in the East Area reservoirs from blocks OML 67, 68 and 70. Production comes from 90 offshore platforms, with 283 flowing completions in 353 wells with a production capacity of about 720,000 barrels of crude, condensate and natural gas liquid (NGL) a day.

\section{3) Liquefied Natural Gas(NLNG) project:}

Nigeria Liquefied Natural Gas is a limited liability company incorporated on $17^{\text {th }}$ May 1989 . It is owned by four shareholders, namely, the Federal Government of Nigeria, represented by Nigerian National Petroleum Corporation (49\%); Shell (25.6\%); Total Gaz Electricite Holdings France (15\%) and Eni (10.4\%), with whollyowned subsidiaries; Bonny Gas Transport (BGT) Limited and NLNG Ship Management Limited (NSML)( NLNG 2019).This project entails liquefying the natural gas that would have been flared and stores in vessels as liquid natural gas. This is achieved by the removal of impurities like water, acid gases and solid particles that are produced with the gas, processing it with the equipment and then store it in a liquid form in vessels as natural gas. The stored Natural Liquefied gas (NLG) can then be used domestically and for industrial purposed or even exported, thereby reducing gas flaring. (Aregbe, 2017)

\section{4) Ekpe Gas Compression Projects:}

The NNPC/MOBIL JV executed this project in order to gather the gas that was being flared in this field for enhancement of oil production by gas lifting and gas re injection

5) Oso 2 Y2 Project:

This project is also being executed by the NNPC/MOBIL JV. Its objective is to provide additional gas make-up for the Oso NGL as well as maintain condensate production of natural gas.

\section{6) Belema Gas Injection Project :}

The NNPC/SHELL Joint Venture is executing this project with an objective to reduce gas flares in Five flow stations by re-injecting some of the gas for gas lifting, some for use as fuel by local industries and the excess for backing out NAG that is currently used to meet various existing contractual obligations, reached advanced stages of execution.

\section{7) Odigbo Node Gas Project :}

The objective of this project is to gather about $113 \mathrm{mmscf} / \mathrm{d}$ of AG from about Six flow stations in the NNPC/Shell Eastern Nigeria Fields, for supply (about $92 \mathrm{mmscf} / \mathrm{d}$ ) to ALSCON (Aluminum Smelting Company of Nigeria) as feed gas and for gas lifting.

\section{8) Odidi AGG Project:}

This project is also being executed by the NNPC/Shell JV in the South Western part of Nigeria. The objective of the project is to gather gas and inject into the ELP (Escravos to Lagos Pipeline), which will eventually form part 
of the West African Gas Pipeline that will supply gas to some West African Countries.

\section{9 ) Cawthorne Channel Gas Injection Project.}

The objective of this project is to gather the gas that is currently being flared in this field for re-injection and for supply to a third party for LPG extraction. The conceptual design is currently on-going.

\section{0) The West African Gas Pipeline Project.}

This WAGP project is in pursuant to Nigeria's commitment to Article 48 of the ECOWAS Treaty, which encourages member Nations to co-operate, consult and coordinate their policies regarding energy and mineral resources. The main goal of WAGP is to harness Nigeria economic benefit from natural gas, reduce and possibly eliminate environmental degradation, create the needed gas infrastructure for the economic benefits of the entire region for sustainable development. Regional energy security is essential to securing sustained gas supply into the broader global market and curtails the wasteful and harmful practice of flaring associated gas. Thus, following the objective of the Treaty, gas produced in Nigeria is transported to other west African countries such as Ghana, Togo, Bene Republic and Cotdivour

\section{1) Efficacy of Past Efforts at Gas Utilization}

The Department of petroleum Resources ( DPR) maintained that flared gas in Nigeria could attract \$3.5 billion investments and enough to generate 2.5 gigawatts $(\mathrm{Gw})$ of power or produce 50 million barrels of oil equivalent (boe) (NNPC, 2017). ${ }^{1}$ It also noted that the flared gas can produce 600,000 metric tons of liquefied petroleum gas (LPG) per year, produce 22 million tons of carbon dioxide (CO2), feed two-three liquefied natural gas (LNG) trains and generate 300,000 jobs, among others. Therefore, the program is considered for its economic, environmental and health implication. It further noted that though Nigeria's gas flaring level is dropping, the quantity of gas flared in 2018 last year was as high as 324 billion standard cubic feet (bscf), while about 888 million standard cubic feet of gas was flared daily in 2017. This is despite Nigeria's efforts at increasing utilization and commercialization of flared gas over the years. It stated that Nigeria still ranks the world's seventh highest gas flaring country, adding that the DPR has identified about 178 flare gas sites or points spread across the Niger Delta in onshore and offshore oil fields; therefore, the agenda is to achieve zero gas flare in Nigeria by 2020. Flared gas constitutes about 11 per cent of the total gas produced in the country, it added.

It is regrettable to emphasis that Nigeria currently have about 202 trillion cubic feet (TCF) of proven gas reserves plus about 600 TCF unproven gas reserves, This day, 2018) ${ }^{2}$ yet about 800 million standard cubic feet (mmscf) of gas is flared every day from approximately 144 gas flared points across Nigeria . (Nigeria gas, 2018) In the bid to cut down this excessive natural gas flaring and introduce measures to utilize the natural gas in the country, the federal government introduced some measures as afore mentioned, Natural Gas projects .These projects, though had been seen by academicians, the government and the society at large as accurate measures of utilizing the natural gas flares in the country, had not realised government 's overall objective - to optimise gas production by avoiding wastage through flaring. These projects over the years have suffered issues of delay in execution (due to lack of finance), lack of infrastructure, obstruction due to pipeline vandalization, political instability, in fact there were cases of divestment from the project sponsors (partners), goal deviation and other associated factors like conflict of interest that has been attributed to the cause of project failures in Nigeria.(Mafimesebi, 2016) For instance the LNG Project had continuously faced issues of lack of infrastructure, inability to build LNG plants and monetize the country's huge gas reserves into sufficient development in the country. The Brass LNG project was awarded at a cost of \$15billion and it is a joint venture between the NNPC with 49 percent, and Italian oil firm Eni ENI.M, French energy giant Total (TOT AF.PA) and ConocoPhillips (COP.N) and pro rata stakes were offered to BG and Centrica (CNA.L). Promoters of Brass LNG, which is currently being constructed in Brass, the Niger Delta region, awarded the FEED contract to Bechtel Corp. In 2004 the award followed the heads of agreement (HOA) signed in October 2003 by shareholders for the development of the two-train LNG plant expected to export $10 \mathrm{MMmt} / \mathrm{y}$ of LNG a year. It was scheduled to begin production between 2009 and 2011 . However, the project has been delayed and it is unclear when the project would be completed. Also the West Africa Gas Pipeline (WAGP), a natural gas project initiated by the Federal Government of Nigeria with the governments of Benin, Ghana, and Togo, designed to supply gas from the Escravos region of Niger Delta, Nigeria to feed generating 
plants of the participating countries. The World Bank and sponsors of the project - Shell and Chevron - had claimed that the WAGP would contribute to putting an end to gas flares in Nigeria, however for more than 10 years after the project was embarked upon, Nigeria still flares more than 1.5 billion cubic feet of natural gas per day. It is estimated that Nigeria loses about $\$ 2.5$ billion yearly due to lack of infrastructure to harness gas. Consequently, the past efforts on curbing gas flaring both legally and infrastructure wise had not significantly reduced gas flaring in Nigeria; hence the current moves by the federal Government to introduce Gas Flare and Commercialisation policy .

\section{4 .Gas Flare Commercialisation Policy (NGFCP)}

The Nigeria' past energy policy aims to promotes the exploration and development of crude oil over and above natural gas and therefore lacks competence and strategies to manage specific legal and fiscal framework needed to attract investment for the development of its vast natural gas reserves(Federal Government, 2003) ${ }^{1}$. Excess nonassociated gas utilized for crude oil operations is often flared depriving the government of much needed additional revenue. Perhaps, in realization of the failure of past legal regime and the consequent loss of revenue from the natural gas sector, the government recently introduced the Nigeria Gas Flare Commercialization Programme (NGFCP, 2019)). ${ }^{2}$ The Gas Flare Commercialization Programme (NGFCP). was launched by the Minister of State for Petroleum Resources ("Minister") on December 13, 2016, and designed as a strategy to implement the policy objective of the federal government by eliminating gas flaring through technically and commercially sustainable gas utilization projects developed by competent third party investors who will be invited to participate in a competitive and transparent bid process. The NGFP is further designed to attract investment to develop its gas market, through a competitive procurement process of allocating gas flare sites to potential investors. The NGFCP is to be hinged on the New Flare Gas (Prevention of Waste and Pollution) Regulations 2018 (Regulation a new regulation issued by the Minister of Petroleum Resources made pursuant to Section.9 of the Petroleum Act and S. 5 of the Associated Gas Reinjection Act (Advocate Law Practice 2018). . According to a DPR's report, "National Gas Flare Commercialization Programme (NGFCP) is key to Nigeria's flare-out agenda with a target for zero routine gas flaring in Nigeria by 2020 . The commercialisation approach though considered from legal, technical, economic, commercial and developmental standpoints, had been considered full proof and accurate.

\subsection{Conditions and qualification of Applicants.}

The Gas flare commercialization policy has thematic procedures and applicants must comply with the conditions set out in order to be considered for the huge investment. To become a qualified applicant, certain minimum requirement must be satisfied and these include (i) Minimum Technical Qualifications, (ii) Minimum Financial Qualifications and (ii) Legal Qualifications for Consortium (where applicable). With respect to Minimum Technical Qualifications, each Applicant must provide information about its technical experience in the design, construction, operation and maintenance of projects of a nature and size similar or larger than US\$5million. Furthermore, each applicant is required to show:

a. Demonstrable project development experience, and;

b. Demonstrable previous experience in either owning or operating gas to power, gas to liquids, gas processing and/or transportation, or similar projects, and;

c. Proven technology in commercial application.

As regards, minimum financial qualification, each applicant must have a net worth (i.e. total assets minus total liabilities) of at least US\$5 million. In addition to the foregoing technical and financial qualification requirements, qualification criteria for a consortium includes:

a. the execution of a Commitment Letter by the Lead Member of the Consortium (the Lead Member must list all members of the consortium and provide a copy of the joint venture agreement or any other document demonstrating their arrangements);

b. execution of a Consortium Letter by all members of the Consortium;

c. power of attorney executed by each member of the consortium; 
d. confidentiality agreement;

e. applicant information form;

f. technical qualifications form;

\section{2 .Main Requirements of the GFCP}

The Regulations as part of its objectives, seeks to curb the waste of natural resources, reduce the environmental and social impact caused by gas flaring and create social and economic benefits from gas flare capture. Similar to the new Angolan law, associated gas not being utilized by the Licensee or Lessee of a Licensed or Leased Area inclusive of marginal fields is to be made available to third party licensees under the procurement process for commercialization. The commercial framework foresees an agreement between the Federal Government and the Flare Permit holder (Flare Licensee) for the sale of contracted Flare Gas volumes to the Flare Licensee - Gas Supply Agreement; an agreement in respect of the connection of the respective facilities of the Operator and the Flare Licensee- Connection Agreement. A key feature of the GSA worthy of consideration during negotiation is the commitment from the Flare Licensee to Take-Or-Pay (TOP) a minimum annual quantity of flare gas. Take-orpay provisions are fairly common in long-term gas supply and off take agreements and are designed to guarantee payment to the seller for a specified quantity of gas even where the buyer is unwilling or unable to take such quantities. It is also common for a buyer with a TOP obligation to seek a reciprocal right to Make-up gas by requesting later delivery as refund of the TOP payment later in the life of the contract. The GSA will likely also include default provisions that gives the seller the right to suspend delivery for non-payment of an invoice. Given the novelty of the NGFCP, the Flare Licensees will most likely be deemed not to be credit worthy and as such the Federal Government is likely to request under the GSA that they either pay in advance for the gas flare volumes, post a stand-by letter of credit or arrange some other form of credit support that will ensure the continued payment for the gas flare volumes received by the Flare Licensee.

There is the likelihood that the Flare Licensee may be supplied off-specification gas by the Operator. In such circumstances, the Flare Licensee's remedy may be limited to the rejection of the off-specification gas. Other remedies that may be considered in negotiation may include the offer of price discounts and allowing TOP credit for any off-specification gas taken by the Flare Licensee. Depending on the circumstances, a better approach may be to place an obligation on the Operator under the Deliver and Pay Agreement to adjust the operating efficiencies of its gas plant if the gas delivered fails to meet contract specifications for two (2) or more consecutive months in a given contract year. There may also be instances of interruption in gas supply which is not excused either by reason of the Flare Licensee's failure to take delivery or Force Majeure. An option may be included in the agreement GAS SUPPLY AGREEMENT CONNECTION AGREEMENT DELIVER OR PAY AGREEMENT WITH THE FEDERAL GOVERNMENT. Licensee OPERATOR in favor of either the Flare Licensee or the Federal Government to make-up the shortfall in a subsequent period and with such later delivery sold at a reduced price (Shortfall gas price). The issue of when title and risk of the flare gas is to be passed to the Flare Licensee is of key importance. The delivery point must be a precisely defined geographical location and based on the contractual arrangements envisaged under the program. It is imperative to determine if the delivery point will be at the Operator's production facility, or the point of entry or exit of a multi-user pipeline. This will assist in determining which party is to bear the risk of transportation of the flare gas volumes. Where the transport arrangement is to be undertaken by a third party, it will be important to consider the extent to which the provisions of the GSA and the Deliver and Pay Agreement must be in alignment, particularly in relation to supply interruptions. Often, force majeure clauses in GSAs do not address the issue as to whether the duration of the contract should be extended according to the time period that parties are prevented from performing the contract. In negotiating the GSA, this potential ambiguity should be addressed by allowing the duration of the contract performance to be extended for a period that is equivalent to the duration of Force Majeure.

Termination events will usually include extended supply interruptions, non-payment of a material amount, delivery of off-specification gas, breach of a material obligation, insolvency, extended events of force majeure, abandonment, termination of certain project documents e.g. Flare license, Connection or Deliver or Pay Agreements. The termination events should be material and where applicable, reasonable cure periods should be negotiated. A connecting agreement is also included.

A CONNECTION AGREEMENT. Given that the flare sites may be in clusters and there may be multiple licensees using common connection facilities, regulatory and competition (antitrust) law issues will need to be considered in relation to access to these common facilities. The Regulation does not presently address the issue of third-party access to processing facilities and pipelines on a non-discriminatory and cost-reflective basis. In addition, with the 
possibility of multiple users of common facilities, issues such as commingling of flare gas volumes will bring to the fore the principles of allocation and attribution as well as balancing which may necessitate additional contractual arrangements. Other issues of note will be infrastructure related such as pipeline crossing, abandonment and decommissioning. This is accompanied with Delivery or Pay agreement.

DELIVER OR PAY AGREEMENT. The Delivery or Pay Agreement signifies a transportation agreement between the Operator and the Flare licensee for the contracted flare gas volumes. It is important that the ship-or-pay obligation of the Operator is sufficiently tight in order to ensure certainty of payment from the Flare Licensee. Though the Regulation provides for a guaranteed fee by the Flare licensee to the Operator. Key considerations in negotiating the contract should include whether the ship-or-pay obligation survives the occurrence of an event of force majeure to the Operators' pipeline and facilities, and whether the Operator has a right of set-off against any amount owed to it by the Flare licensee. Other aspects of the Operator's delivery obligations to take into consideration are the point-of-delivery as discussed above, delivery pressure and minimum quality specifications. Also as stated above, there must be consideration for third -party access on a non-discriminatory basis to the Operators facilities.

\subsection{How Effective is the NGFCP}

The National Oceanic and Atmospheric Administration (NOAA), stated that the GFCP since 2016 when it was launched, has not recorded significant success story. This is evident in the fact that the year 2018 had more gas flares burning more intensely than has been seen for the past five years in Nigeria which evidently led to the country's 2018 rank of sixth (6th) global Natural Gas Flare nations. (Nigerian Senate 2019) ${ }^{1}$ In fact, recently, the senate(National Assembly) raised alarm that the huge revenue loss due to unrelenting Gas flares in Nigeria stood at over N197bn, following data obtained from the Nigerian National Petroleum Corporation (NNPC) that Oil and gas firms operating in the country flared a total of 215.9 billion standard cubic feet (SCF) of natural gas. Also, oil and gas firms last year, according to the Nigerian National Petroleum Corporation (NNPC) flared a total of 282.08 billion standard cubic feet of natural gas, which was put at a loss of N234 billion. The question lies either in the poor implementation of conspiracy theory between the federal government of Nigeria and the core investors -the IOC who prefer to flare gas than to reinject gas for commercial purpose- being the same trademark that saw the death of the past legal frameworks on gas flaring reduction mechanism of the federal government of Nigeria. However, it was hoped that the FG, will attract major investment through gas flare capturing for sales to competitive bidders. But it is yet to be seen how successful the implementation would go to achieving the government's desired objectives as the policy is yet to take off fully due to hiccups and other operational failures due to lack of political will. Again, it is apposite that the Program could be caught us by the coronavirus pandemic COVID-19 and its associated economic loses to all nations. Incidentally, the year 2020, is here with us; showing how risky and unplanned the concept appears.

\section{Conclusion.}

The consequence of the current regulation is that the government owns the flared gas and the producer has no title to the flared gas. It can allocate it to competent companies that can take it to the market place; so, it's government's right. Nations (Newspaper 2020). Third party right is encouraged to lift gas produced and operators are equally incentivized to produce gas for off takers this is achieved through a connecting agreement, which will save operators of gas flaring penalty. The scheme operates thus to increase the flared gas payments to the federal Government while protecting the health, safety and environment of Nigerians. The policy will create options for Bidders who will have flexibility of choosing which flare site (s) to bid for, determine the gas price, and their enduse market or gas product, as well as the technology to be deployed. The Bidders will demonstrate through statement of intent or qualification that it has project development experience and proposed proven technology, which we expect to be in commercial application." The option is also open to a company to participate in more than one consortium. We found that if all the hiccups are controlled and managed the NGFCP will help to reduce the incident of illegal refiners and gas flaring in Nigeria delta communities of Nigeria and more jobs would be created by the federal government. We thus recommend that most of the condition be relaxed to allow new applicant who can demonstrate competence to buy into the program notwithstanding that the applicant does not have past industry pedigree in the gas sector 


\section{References}

1. . Agbonifo, P E,(2016) 'Natural Gas Distribution Infrastructure and the Quest for Environmental Sustainability in the Niger Delta : the Prospect of Natural Gas Utilization in Nigeria' IJEEP 6(,3) 444-445

2. Aghalino, S O, (2009) Gas Flaring, Environmental Pollution and Abatement Measures in Nigeria 1969-2001", JSDA Vol 11, no 4, ISSN $1520-5509$ at 221.

3. Aregbe, A G,(2017) 'Natural Gas Flaring -Alternative Solutions" WJET 5, 147,

4. Advocate law Practice (2018) ' 'A publication of Energy and Infrastructure group of Advocate Law practice 2018' <https://www.advocaat-on lin law.com/assets/resources/efede50bb21dbdd1cc8725316b057bf4.pdf $>$ accessed 2 March, 2020.

5. Associated Gas Re Injection At 1979 and Associated Gas (Continuing flaring) Amendment Act 1985

6. Associated Gas Re-injection Act 1979

7. Akpan, G S,(2005) 'The failure of Environmental Governance and Implication for foreign investors and host State: Astudy of Niger Delta region of Nigeria $O G E L$, (3 ) 3 15-18.

8. Chevron Highlights Nigeria Gas Success Story, Energy Mix Report, November (2019) htps://www.energymixreport.com/chevronhighlights-nigerian-gas-success-story/ acceesed 5 march 2020

9. Dike, S C Energy Security (2015), the case of Nigeria and Lessons from Brazil, Norway and UK.,Pearle publishers 80.

10. Egbuchi A S, , Nigerian Gas Master-Plan \& Sustainable Economic Growth (2008), $<$ http://www.nse.org.ng/yankari08/EGBU\%20SQUARE.ppt $>$. last accessed on December 15 ${ }^{\text {th }}$ March 2020

11. Energy Commission of Nigeria (2003) National Energy Policy12-18.

12. Environmental Right Action/Climate Justice: (2005) 'Gas flaring in Nigeria a human Right, Environmental and Economic monstrosity) Netherlands 20050-5 <eraction.org>. accessed 5 January 2020.

13. Escravous Gas-to-Liquids Projects, Niger Delta, 1998 Feasibility Study, http://www.hydrocarbons-technology.com/projects/escravous/ last visited on $8^{\text {th }}$ March 2020.

14. Federal Government of Nigeria, First and Second Country Country's Submission to the United Nations Framework Convention on Climate change 2003 and 2015

15. Federal Government of Nigeria, National Energy Policy 2003

16. Onyeukwu, H, ' Nigerian Gas Master Plan and Policy: Is It a Constrained Energy Policy”, (2009)

17. Nigerian Oil and Gas Industry Content Development Act 2010.

18. Gas Pricing Framework Under Threat Amid Power Sector Crisis (2019) http://www.punchng.com/gas on line accessed 5 March 2020

19. 'Nigerian Gas Flare Commercialization Program me, 2019', see http://www.Ngfcp.dpr.gov.ng last visited $13^{\text {th }}$ March 2020. $<$ https://thenationonlineng.net/how-flared-gas-commercialisation-can-work/ accessed 23 March 2020

20. Nwaozuzu, C, (2014) 'Maximizing the use of Natural Gas in Nigeria; Prospects, Constraints and Potential Solutions Energy Mix report, $<$ https;//www.energymixreport.com/maximizing -the-use-of-natural-gas-in-nigeria-prospects-constraints-and-potential-solutions $>$ last visited on $6^{\text {th }}$ March 2020

21. Onwukwe, S ( 2009)' 'Gas to Liquid Technology: Prospect for Natural Gas Utilization in Nigeria” JNGSE 1, 190

22. National Gas Policy -Series 1 (Governance \&Industry Structure) ( 2017) http://www.olaniwunajayi.net/blog/national-gas-policy-seriesi/ last accessed 15the March 2020

23. Nigeria ( 2018) The Nigerian Gas Flare Commercialization Programme: A Win-Win Situation, A $<\mathrm{http}$ //wwwMondaq.com/Nigeria/x/689396/oil+gas=electricity/the+Nigeria+gas+flar+commercialization+programme+A+winwin+sit uation $>$ last visited on the $13^{\text {th }}$ March 2020.

24. Nigerian National Petroleum Corporation (2017) Draft Annual Statistical Bulletin.

25. NLNG (2012), Profile, http//www.nlng.com-company/pages/profile.aspx last visited $8^{\text {th }}$ March 2020

26. NNPC, (2008) Nigeria's Gas Master Plan 2008'.

27. Mafimisebi, O P (2016) 'Project Management Practice: Lessons Learnt from Project Failures in Nigeria" EJBM 8(1) issn 2222-1905, 108.

28. Oil Pipelines Act cap 338, LFN 1990.

29. Petroleum (Drilling and Production Regulation) 1991

30. Petroleum Act 2004

31. .Iyiola, S,. Oyewo, M A, (2011), 'Gas Flaring, Transportation and Sustainable Energy Development in the Niger Delta, Nigeria' JHE 33(1) 21-23

32. Okoroji, CE (1996) Progress and prospect for Nigeria's LNG ; paper presented at SPENC 9613 Society for Petroleum Engineers Annual Conference and Exhibition

33. Senate Monitors Implementation of Nigerian Gas Flare Commercialization Programme, to Review Penalty, $2019<$ http://www.oglinks.news/nnpc/news/senate-monitors-implementation-nigerian-gas-flare-commercialization $>$ last accessed on 13, March 2020.

34. The Nations Newspaper: How flared gas commercialization can work

35. This day Newspaper, ( 2018) Nigeria; NNPC-Nigeria's Gas Reserves now 2002trn cubic feet. https;//www.allafrica.com/stories/201810230053/htm last visited $6^{\text {th }}$ March 2020

36. World Bank. 1991. Nigeria - Oso Condensate Field Development Project (English). Washington, DC: World Bank. http://documents.worldbank.org/curated/en/834791468291017038/Nigeria-Oso-Condensate-Field-Development-Project last visited on 8th March 2020.

37. World Bank's Global Gas Flaring Reduction Partnership Ranking from July 2018 ,

38. Shchick L, .Myles, P, Okelum O E,(2018) 'Gas Flaring Continues Scorching Niger Delta' Top Stories Media Center, see http://www.dw.com/en/gas-flaring-continues-scorching-Niger-delta/a.46088235 last visited on March 2020.

39. Omorogbe, Y ('1996) Law and Investors Protection in Nigeria Natural Gas Industry`1 Journal of Energy and Natural Resources Law 181-182 